\title{
Effect of trace minerals and starch on digestibility and rumen fermentation in diets for dairy heifers ${ }^{1}$
}

\author{
F. Pino and A. J. Heinrichs ${ }^{2}$ \\ Department of Animal Science, The Pennsylvania State University, University Park 16801
}

\begin{abstract}
The objective of this study was to evaluate the effect of different forms of trace minerals (TM) and the use of different starch levels in dairy heifer diets on rumen fermentation and digestibility. Eight rumen cannulated dairy heifers $(15.4 \pm 0.8 \mathrm{mo}$ of age and $438.31 \pm 18.08$ $\mathrm{kg}$ of body weight) were subjected to a split-plot, $4 \times 4$ Latin square design with 19-d periods: $15 \mathrm{~d}$ of adaptation and $4 \mathrm{~d}$ of sampling. The whole-plot factor was type of TM; organic as proteinates (OTM) or inorganic sulfates (ITM), and the subplot was starch level (3.54, $12.95,22.25$, and $31.73 \%$ ). Total collection of feces and urine was completed on d 15 to 19 to determine digestibility and TM excretion. Rumen contents were sampled on d 18 to 19 at $0,1,2,4,8,12,16,20$, and $22 \mathrm{~h}$ after feeding to measure $\mathrm{pH}$ and volatile fatty acid (VFA) concentrations. Plasma samples were collected to evaluate TM concentrations and enzymatic activity for ceruloplasmin, glutathione peroxidase, and superoxide dismutase. Starch level affected $\mathrm{pH}$, individual VFA concentrations, and nutrient excretion. Trace mineral intake was lower for OTM compared with ITM. No effect of TM form on dry matter digestibility was detected, but as level of starch increased, diet dry matter digestibility increased. Rumen $\mathrm{pH}$ was lower for diets with OTM, which is consistent with higher total VFA production and butyrate proportion observed for heifers fed OTM diets. These variables may be explained by the higher bioavailability of OTM and faster utilization and fermentation by rumen microorganisms. Heifers that consumed ITM had higher moisture in feces and higher urine excretion, which increased total manure production. Total excretion of TM was not different by treatment. Blood plasma mineral concentration was not different between treatments except for $\mathrm{Mn}$, which was higher for OTM. Enzymatic activity was not affected

\footnotetext{
Received June 30, 2015.

Accepted December 23, 2015.

${ }^{1}$ This research was a component of NC-2042, Management Systems

${ }^{2}$ Corresponding author: ajh@psu.edu
} to Improve the Economic and Environmental Sustainability of Dairy Enterprises.
\end{abstract}

by treatments. Mineral intake was reduced and blood mineral levels were not different, suggesting enhanced absorption of OTM compared with ITM. In conclusion, based on rumen $\mathrm{pH}$, VFA production, and plasma TM concentration, OTM may be more ruminally bioavailable and absorbed to a greater extent than ITM. Also, TM form affected fecal moisture and urine excretion, suggesting that ITM may stimulate water intake.

Key words: heifer, trace mineral, starch

\section{INTRODUCTION}

Finding strategies to raise dairy heifers economically and efficiently is an important issue for dairy farms. Dairy heifers are often fed a diet based on high levels of lower quality forages. However, diets with higher nutrient density and higher digestibility are known to improve feed efficiency. Thus, heifers decrease the energy used for digestion and enhance the energy used for growth when fed highly digestible diets (Zanton and Heinrichs, 2007). Although this practice is commonly used both in research and on commercial farms, it still generates some concern. The high proportion of concentrates in nutrient-dense diets could lead to low ruminal $\mathrm{pH}$ due to rapid fermentation in the rumen. Also, high concentrations of starch in the diet can reduce fiber digestion (Piwonka et al., 1994). Studies have reported normal growth and no effect on rumen health (Hoffman et al., 2007; Lascano et al., 2009) with more digestible, higher concentrate diets fed to heifers. Offering highstarch diets $60 \mathrm{~d}$ before breeding can have a positive effect on puberty, with heifers presenting estrus 24 to $22 \mathrm{~d}$ earlier compared with heifers fed low-starch diets in trials designed for ADG of $0.9 \mathrm{~kg} / \mathrm{d}$ (Zanton and Heinrichs, 2007). At the same time, with high-starch diets heifers were $31 \mathrm{~kg}$ lighter than with low-starch diets (Ciccioli et al., 2005). Studies have reported that a large proportion of concentrate in the diet produces higher levels of VFA, which could saturate epithelial cells in the rumen wall and decrease the absorption rate of nutrients. This situation occurs because the majority of the processes in the cell are regulated and limited by enzymes that require micronutrients such as vitamins 
and trace minerals (TM) for their function (Storm et al., 2012). When the availability of these micronutrients is limited, the body cells show a low performance and metabolism.

Trace minerals such as $\mathrm{Zn}, \mathrm{Mn}, \mathrm{Cu}$, and Co are required for structural proteins, enzymes, coenzymes, and cellular proteins and participate in many enzymatic processes in the rumen (Durand and Kawashima, 1980). This produces changes in the ruminal environment, affecting the production of VFA, digestibility of fiber, and digestion of feed. In vitro, some TM can depress cellulose digestion depending on the added level (Hubbert et al., 1958). In the same way, they could modify microbial populations and metabolic pathways in the rumen. Studies have reported that cellulose digestion decreases due to TM deficiencies at high levels of starch (Summers et al., 1957). This can occur because fast-growing bacteria (present in cattle fed high-grain rations) increase the microbial TM requirement when they are degrading starch and there is not enough TM to be used by slow-growing bacteria that are cellulose digesters (Summers et al., 1957). Studies show when levels of Mo or Co are low in the diet, fiber digestibility decreases (Durand and Kawashima, 1980; Tiffany and Spears, 2005). After supplementation of $\mathrm{Cu}$ and $\mathrm{Co}$ in ruminants fed a low TM diet, fiber digestibility and cellulose degradation increased. Supplementation with TM can also modify the molar proportions of VFA (Underwood and Suttle, 1999). In diets deficient in Se, the ruminal molar proportion of isovaleric acid increased after adding Se to the diet (Durand and Kawashima, 1980). This situation was explained by increased activity of seleno-enzymes (Durand and Kawashima, 1980). Information is limited about how the form of TM (inorganic or organic form) affects these ruminal processes.

Considering TM blood concentration, studies suggest that organic minerals are better absorbed than the inorganic forms (Spears, 1996). Also, organic TM (OTM) are more available for metabolic processes because they are more similar to the natural forms of presentation in the body (organic complexes rather than free inorganic ions). The organic mineral form avoids the formation of mineral complexes (e.g., thiomolybdates) or associations with other dietary components that reduce TM absorption and availability for metabolic functions (Durand and Kawashima, 1980). Additionally, due to the increased bioavailability of organic minerals, the amount supplied in the diet can be reduced, decreasing excretion and lessening the potential for environmental damage.

It has been shown that $\mathrm{pH}$ can modify the solubility of TM. Organic forms of $\mathrm{Zn}, \mathrm{Mn}$, and $\mathrm{Cu}$ are more soluble when $\mathrm{pH}$ decreases, increasing absorption and availability in the small intestine. Microorganisms can use both soluble and insoluble forms of elements in the rumen for bacterial metabolism (Cao et al., 2000). It is necessary to determine the specific functions of $\mathrm{TM}$ in the ruminal environment and how they affect microbial metabolic pathways. The aim of this study was to evaluate starch utilization and effect of TM on the rumen using different concentrations of starch and supplementing with 2 forms of TM in precision-fed (limit fed) dairy heifers. Thus, this study evaluated total-tract nutrient utilization, the ruminal environment, digestibility parameters, and TM total-tract absorption and bioavailability.

\section{MATERIALS AND METHODS}

\section{Animals, Treatments, and Experimental Design}

All procedures involving the use of animals were approved by the Pennsylvania State University Institutional Animal Care and Use Committee (\#42881). Eight Holstein heifers (15.4 $\pm 0.8 \mathrm{mo}$ of age and 438.31 $\pm 18.08 \mathrm{~kg}$ of BW) fitted with a $10-\mathrm{cm}$ rumen cannula (Bar Diamond, Parma, ID) were used in a split-plot, 4 $\times 4$ Latin square design with 4 heifers in each plot, $19-\mathrm{d}$ periods including $15 \mathrm{~d}$ of adaptation and $4 \mathrm{~d}$ of sampling. The whole-plot factor was type of TM supplemented (inorganic trace mineral ITM as sulfates and organic trace mineral OTM as proteinates and yeast): Bioplex $\mathrm{Cu}, \mathrm{Mn}, \mathrm{Zn}$, and Sel-Plex (Alltech Inc., Nicholasville, KY). The subplot was level of starch in the diet (3.54, $12.95,22.25$, and $31.73 \% \mathrm{DM})$. Heifers were kept in tiestalls $35 \mathrm{~d}$ before the experiment (pretrial adaptation period to adapt heifers to the facility and management as well as to recover from the cannulation surgery) and then were randomly assigned to treatments. Heifers were weighed weekly, and BW was determined by the average of 2 measurements taken on the same day. The amount of TMR offered during the experiment was adjusted weekly based on BW to allow an average of 0.8 to $0.9 \mathrm{~kg} / \mathrm{d}$ of ADG (Lascano and Heinrichs, 2011). Heifers were housed in individual tie-stalls in a mechanically ventilated barn. Heifers had free access to water and intake was recorded during sampling days with volume flow meters (Sensus Metering Systems, Uniontown, PA). The animals were released for exercise $3 \mathrm{~h} / \mathrm{d}$ in a paved pen on nonsampling days.

\section{Diets}

Rations were fed once daily as TMR, and predicted DMI was calculated based on energy intake with diets 
Table 1. Ingredient and chemical composition of treatment rations offered containing inorganic trace minerals (ITM) or organic trace minerals (OTM) and 4 levels of starch

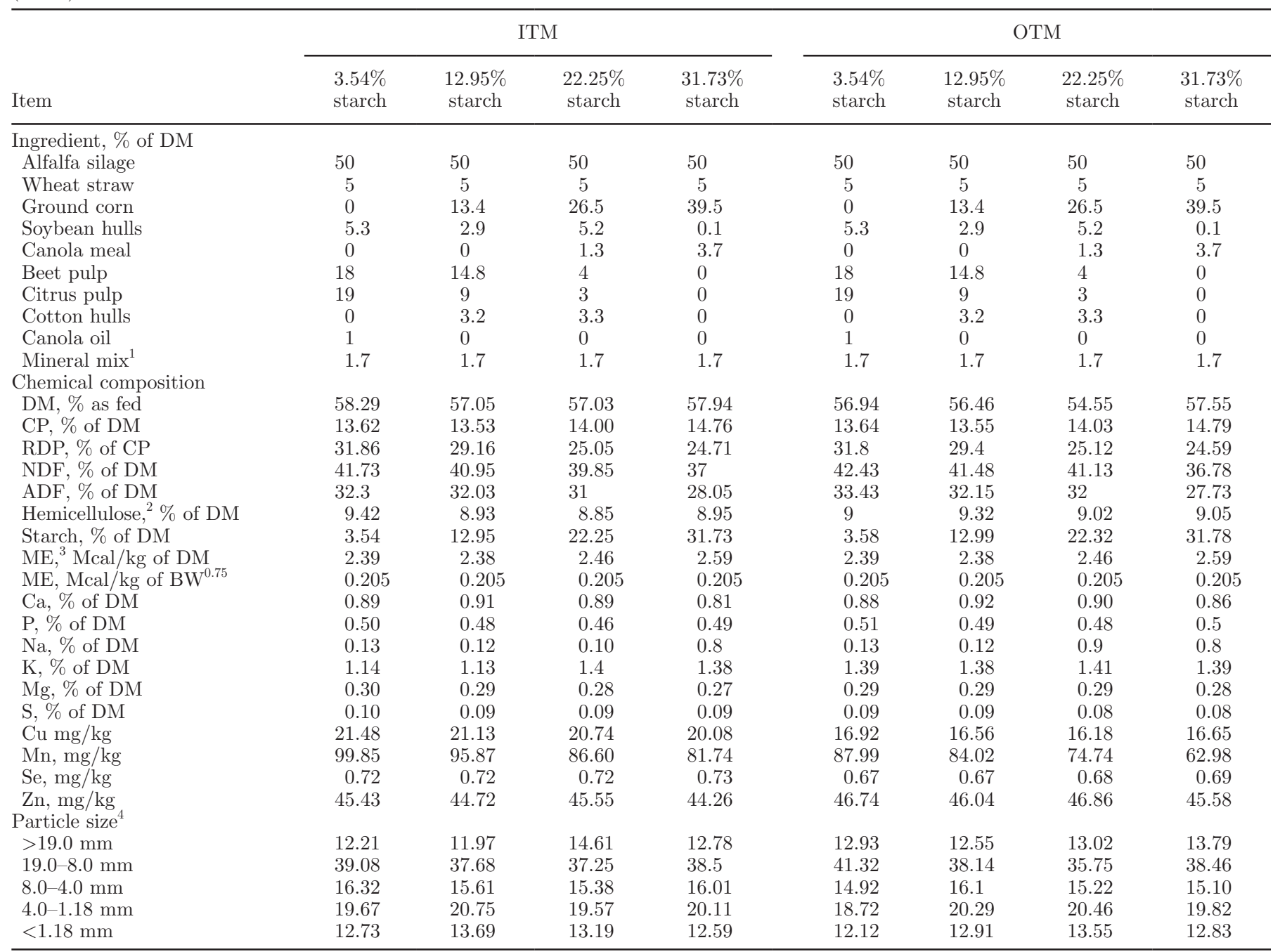

${ }^{1}$ Mineral mix, Alltech, Nicholasville, KY. Inorganic trace minerals (TM) contained $94.28 \%$ DM, 11.65\% CP, 1.7\% soluble CP, 5.46\% RUP, 8.29\% $\mathrm{ADF}, 19.2 \% \mathrm{NDF}, 5.5 \%$ fat, $12.4 \% \mathrm{Ca}, 0.36 \% \mathrm{P}, 2.63 \% \mathrm{Mg}, 0.44 \% \mathrm{~K}, 0.39 \% \mathrm{~S}, 1,628.87 \mathrm{mg} / \mathrm{kg}$ of $\mathrm{Mn}, 542.71 \mathrm{mg} / \mathrm{kg}$ of $\mathrm{Cu}, 1,639 \mathrm{mg} / \mathrm{kg}$ of $\mathrm{Zn}, 232.94 \mathrm{mg} / \mathrm{kg}$ of Fe, $9.90 \mathrm{mg} / \mathrm{kg}$ of Se, $9.2 \mathrm{mg} / \mathrm{kg}$ of Co, $22.2 \mathrm{mg} / \mathrm{kg}$ of I, $70.748 \mathrm{UI} / \mathrm{g}$ vitamin A, $17.637 \mathrm{UI} / \mathrm{g}$ vitamin D, and $1.230 \mathrm{UI} / \mathrm{g}$ of vitamin E. All ITM were added as sulfates. Organic TM contained 93.81 DM, 13.9 CP, 2.5\% soluble CP, 5.46\% RUP, 5.8\% ADF, 14.37\% $\mathrm{NDF}, 5.8 \%$ fat, $13.2 \% \mathrm{Ca}, 0.42 \% \mathrm{P}, 2.81 \% \mathrm{Mg}, 0.51 \% \mathrm{~K}, 0.41 \% \mathrm{~S}, 1,738.53 \mathrm{mg} / \mathrm{kg}$ of $\mathrm{Mn}(1,732.57 \mathrm{mg} / \mathrm{kg}$ of organic), $581.53 \mathrm{mg} / \mathrm{kg}$ of Cu (575.77 mg/kg of organic), 1,756.62 mg/kg of Zn (1,718.47 mg/kg of organic), $240.15 \mathrm{mg} / \mathrm{kg}$ of Fe, $10.62 \mathrm{mg} / \mathrm{kg}$ of Se (organic), $9.84 \mathrm{mg} / \mathrm{kg}$ of Co $(274.91 \mathrm{mg} / \mathrm{kg}$ of organic), $23.62 \mathrm{mg} / \mathrm{kg} \mathrm{I}, 75.50 \mathrm{IU} / \mathrm{g}$ of vitamin A, $18.79 \mathrm{IU} / \mathrm{g}$ of vitamin D, and 1,321.1 IU/g of vitamin E. Organic TM were added as proteinates.

${ }^{2}$ Hemicellulose $=$ NDF - ADF

${ }^{3} \mathrm{ME}$ calculated as TDN $\times 0.04409 \times 0.82$

${ }^{4}$ Measured with Penn State Particle Separator.

formulated to provide $0.23 \mathrm{Mcal}$ of $\mathrm{ME}$ intake $/ \mathrm{kg}$ of empty $\mathrm{BW}^{0.75}$. Nitrogen intake was balanced to $1.8 \mathrm{~g}$ of $\mathrm{N} / \mathrm{kg}$ of empty $\mathrm{BW}^{0.75}$. Dry matter of alfalfa silage was measured daily in a microwave as described by Pino and Heinrichs (2014), and forages (50\% alfalfa silage and $5 \%$ wheat straw) were mixed daily in a Calan Super Data Ranger (American Calan, Northwood, NH). Grain mixes were formulated to provide 3.54, 12.95, 22.25 , and $31.73 \%$ starch concentration (DM; Table 1) when included in the ration and were prepared before each period as a single mix. Rations were formulated to provide a 55:45 forage-to-concentrate ratio. Minerals were added daily to the TMR before mixing for each individual heifer. Byproduct feeds were added to rations to replace corn in lower starch diets and to reduce energy levels in diets. Eating times (minutes to consume the entire daily ration) were recorded daily during sampling days. 


\section{Sample Collection and Analysis}

Feedstuffs were collected before every period, and TMR was collected daily during the 4 sampling days to be composited by period, dried in a forced-air oven at $55^{\circ} \mathrm{C}$ for $48 \mathrm{~h}$, and ground through a $1-\mathrm{mm}$ screen (Wiley mill, Arthur H. Thomas, Philadelphia, PA) for further analysis. Particle size was analyzed daily (Penn State Particle Separator with 19-, 8-, 4-, and 1.18-mm sieves) during sampling days and a sample of TMR was saved for analysis.

Urine was collected from d 15 to 20 using the modified cup collector described by Lascano et al. (2010). Urine $\mathrm{pH}$ was acidified to $\mathrm{pH} 2$ by the addition of $1 \mathrm{~L}$ of $10 \% \mathrm{HCl}$ solution in an 18.9-L bucket to minimize $\mathrm{NH}_{3}$ volatilization. During sampling days, total urine was weighed, recorded, and subsampled daily after feeding. At the end of each period urine samples were composited, and a $250-\mathrm{mL}$ subsample was frozen at $-20^{\circ} \mathrm{C}$ until analysis.

During sampling days, feces were collected hourly and stored in airtight containers. After feeding, daily feces were mixed and a subsample was saved at $4^{\circ} \mathrm{C}$ to be composited at the end of each period. Then the subsample was dried in a forced-air oven at $55^{\circ} \mathrm{C}$ for $72 \mathrm{~h}$ and ground through a 1-mm screen (Wiley mill, Arthur H. Thomas, Philadelphia, PA) for further analysis.

The composited and dried feeds and fecal samples were analyzed for DM, ash, and CP (AOAC International, 2000; methods 934.01, 942.05, and 968.06, respectively), NDF, and ADF were analyzed individually (Van Soest et al., 1991). Analysis of NDF included use of heat-stable $\alpha$-amylase (Sigma Chemical Co., St. Louis, MO) and sodium sulfite (Van Soest et al., 1991) using an Ankom ${ }^{200}$ fiber analyzer (Ankom Technology Corp., Fairport, NY). Rumen degradable protein was calculated from feeds that were analyzed in Cumberland Valley Analytical Services Inc. (Maugansville, MD). Starch and soluble sugars were determined by the method of Hall (2009), using previously ground samples that were reground to pass through a $0.5-\mathrm{mm}$ screen. Metabolizable energy intake was estimated for each heifer within each period using the observed OM intake $\times 4.409 \times 0.82$ as described in NRC (2001).

Blood samples $(10 \mathrm{~mL})$ were taken on d 15 of each period from the coccygeal vein into serum tubs containing clot activator (Becton Dickinson Vacutainer Systems) and another 10-mL sample into evacuated plasma tubes with sodium heparin (Becton Dickinson Vacutainer Systems). Serum and plasma were separated from blood by centrifugation at $1,300 \times \mathrm{g}$ at $4^{\circ} \mathrm{C}$ for $15 \mathrm{~min}$. Serum and plasma were stored at $-20^{\circ} \mathrm{C}$ until analysis for minerals.
Concentrations of selected minerals $(\mathrm{Cu}, \mathrm{Mn}, \mathrm{Se}$, and $\mathrm{Zn}$ ) were measured in feeds, feces, urine, and plasma using an optic emission spectrophotometer (ICP-OES Optima 7300 DW, Perkin Elmer Inc., Waltham, MA) using samples that were previously digested with nitric acid. For all TM analyses, acid digestion was used instead of ashing to avoid volatilization of Se (Cornelis et al., 1995). All glassware used for sample digestion was washed with $10 \%$ nitric acid overnight and then rinsed 10 times with double-distilled water to avoid contamination of the sample with TM. Feed TM were digested in an open vessel using $0.5 \mathrm{~g}$ of sample (samples were previously reground to pass through a $0.5-\mathrm{mm}$ screen) placed in a $250-\mathrm{mL}$ flask. Five milliliters of nitric acid was added, and then flasks were covered with watchglasses and placed on a hot plate at $40^{\circ} \mathrm{C}$ for $40 \mathrm{~min}$ followed by $95^{\circ} \mathrm{C}$ for $120 \mathrm{~min}$. After the flasks were cooled, samples were transferred to a $50-\mathrm{mL}$ volumetric flask and diluted (to $50 \mathrm{~mL}$ ). Five milliliters of the diluted sample was placed into a $15-\mathrm{mL}$ polypropylene tub and analyzed in the ICP-OES (adapted from Rodushkin et al., 1999). Macro minerals were analyzed by Cumberland Valley Analytical Services Inc.

Fecal minerals were analyzed by weighing $0.3 \mathrm{~g}$ of composited sample into screw-capped borosilicate tubes, then adding $2.0 \mathrm{~mL}$ of nitric acid and $0.5 \mathrm{~mL}$ of hydrogen peroxide. Tubes were vortexed and held at room temperature $\left(20\right.$ to $\left.22^{\circ} \mathrm{C}\right)$ overnight. Tubes were re-vortexed and placed in a water bath at $80^{\circ} \mathrm{C}$ for $30 \mathrm{~min}$ followed by $100^{\circ} \mathrm{C}$ at $120 \mathrm{~min}$. Samples were transferred to a $50-\mathrm{mL}$ volumetric flask and diluted to $50 \mathrm{~mL}$. Five milliliters of the diluted sample was placed into a $15-\mathrm{mL}$ polypropylene tub and analyzed in the ICP-OES. Urine samples were digested with nitric acid with a method adapted from Vaughan et al. (1991), using a water bath instead of a block heater digester.

When digesting plasma samples for TM analysis, some samples had an oil layer (not soluble in acid or water) that interfered with the spray in the ICP-OES system. This oil corresponded to plasma lipids, which have been reported to not contain minerals (Vaughan et al., 1991); hence, this layer was removed before TM determination. The settings used in the ICP were as follows: gas flow, $15 \mathrm{~L} / \mathrm{min}$; nebulizer, $0.8 \mathrm{~L} / \mathrm{min}$; radio frequency power, $1,300 \mathrm{~W}$; and pump flow rate, 1.5 $\mathrm{mL} / \mathrm{min}$. The wavelengths used were as follows: $\mathrm{Cu}$ $324.752 \mathrm{~nm}$ for plasma, feeds, and feces and $213.59 \mathrm{~nm}$ for urine; Mn $259.372 \mathrm{~nm}$ for plasma, $279.482 \mathrm{~nm}$ for feeds, and $257.621 \mathrm{~nm}$ for feces and urine; Se 196.026 $\mathrm{nm}$ for all samples; Zn $330.258 \mathrm{~nm}$ for plasma, 213.857 $\mathrm{nm}$ for feeds and feces, and $202.548 \mathrm{~nm}$ for urine.

Plasma and serum were used to measure glutathione peroxidase $(\mathbf{G P x})$, superoxide dismutase (SOD), and 
ceruloplasmin activity as a method to determine the utilization of $\mathrm{Se}, \mathrm{Zn}$, and $\mathrm{Cu}$, respectively, by heifers as previously described (Dezfoulian et al., 2012). To measure enzymatic activity, colorimetric assay kits were used (\#K699-100 for ceruloplasmin; \#K762-100 for GPx; and \#K355-100 for SOD; BioVision Inc., Milpitas, CA).

Rumen fluid samples were taken on d 18 from 5 locations in the rumen (dorsal, ventral, anterior, caudal, and central) at $0,1,2,4,8,12,16,20$, and $22 \mathrm{~h}$ relative to feeding time. Rumen fluid was strained through a 0.28-mm fiberglass mesh screen (New York Wire, Mt. Wolf, PA), $\mathrm{pH}$ was recorded ( $\mathrm{pH}$ meter, model M90, Corning Inc., Corning, NY), and strained fluid was placed in 5 -mL tubes with $1 \mathrm{~mL}$ of $0.6 \%$ 2-ethylbutyric and $1 \mathrm{~mL}$ of $25 \%$ metaphosphoric acid at $-20^{\circ} \mathrm{C}$ for VFA analysis (Yang and Varga, 1989).

\section{Statistical Analysis}

All statistical analyses were conducted in SAS (9.3, SAS Institute Inc., Cary, NC) using the MIXED procedure. Dependent variables were analyzed as a splitplot $4 \times 4$ Latin square design with TM type as the whole plot and level of starch as the subplot. Heifers were considered experimental units because they were individually fed and intake and ADG were known. All denominator degrees of freedom for $F$-tests were calculated according to Kenward and Roger (1997). The model used was

$$
\mathrm{Y}_{\mathrm{ijkl}}=\mu+\mathrm{T}_{\mathrm{i}}+\mathrm{S}_{\mathrm{j}}+\mathrm{N}_{\mathrm{k}(\mathrm{i})}+\mathrm{TS}_{(\mathrm{ij})}+\mathrm{P}_{1}+\mathrm{e}_{\mathrm{ijkl}} \text {, }
$$

where $Y_{\mathrm{ijkl}}$ is a continuous dependent response variable; $\mu$ is the overall mean; $T_{i}$ is the fixed effect of TM treatment $(i=1,2) ; S_{j}$ is the fixed effect of level of starch $(j$ $=1,2,3,4) ; \mathrm{N}_{\mathrm{k}(\mathrm{i})}$ is the random effect of heifer within TM treatment; $\mathrm{TS}_{(\mathrm{ij})}$ is the interaction of TM and level of starch; $\mathrm{P}_{1}$ is the period effect; and $\mathrm{e}_{\mathrm{ijkl}}$ is the residual error. Repeated measures were used to analyze rumen $\mathrm{pH}$ and VFA using $\mathrm{SP}(\mathrm{POW})$ because covariance structure for time intervals not evenly spaced. Time and time $\times$ treatment interaction were included in the model for rumen $\mathrm{pH}$ and VFA. Residual variances were assumed normally distributed, and all data are presented as least squares means. The $P$-values for the linear, quadratic, and cubic effects and their interactions were analyzed using orthogonal polynomials contrasts. Cubic effects were not significant, and thus were not shown in the tables. Differences were declared significant at $P \leq 0.05$ and tendencies at $P \leq 0.10$ for main effects.

\section{RESULTS AND DISCUSSION}

Diet ingredients, chemical composition of individual ingredients, and particle size are presented in Table 1. Ingredients were analyzed for each period to report composition of the diets. Alfalfa silage was $18.3 \% \mathrm{CP}$, 13.6 RDP, $41.4 \% \mathrm{NDF}, 34.5 \% \mathrm{ADF}$, and 2.32 ME of $\mathrm{Mcal} / \mathrm{kg}$. The rations were formulated to provide equal ME per kilogram of $\mathrm{BW}^{0.75}$ with different levels of starch $(3.54,12.95,22.25$, and $31.73 \%$ on a DM basis) for ITM and OTM, respectively. To achieve these different levels of starch, beet pulp and citrus pulp were gradually replaced by ground corn to obtain a higher starch proportion in the diet. Crude protein changed depending on the starch level due to the different proportion of feedstuffs in the diet. The TMR particle size distribution was not different between treatments.

Initial and final BW were not different by plot (LSM $\pm \mathrm{SD} ; 433.23 \pm 19.66$ vs. $463.08 \pm 17.52$ for ITM or OTM; $509.05 \pm 15.1$ vs. $509.73 \pm 13.29$ for ITM or OTM at the beginning and at the end of the experiment, respectively; Table 2). For all the analyses, TM $\times$ starch interactions were not significant and therefore are not presented in the tables. In the case of tendencies, these will be stated in the results.

\section{Nutrient Intakes and Diet Digestibility}

Heifers were precision fed $(1.75 \%$ of BW on DM basis) as preplanned, with nutrient and TM intakes shown in Table 2. Dry matter intake was not different by TM but, by design, linearly declined as the proportion of starch increased to keep the same amount of ME per kilogram of $\mathrm{BW}^{0.75}$. The ADG $(800 \mathrm{~g} / \mathrm{d})$ was similar for both TM treatments, but presented a quadratic response that followed the same trend as DMI. Feed efficiency was not different by TM form or starch level. In general, NDF, ADF, hemicellulose, $\mathrm{CP}$, ash, soluble sugars, and calculated ME intake decreased linearly, whereas starch intake increased linearly. Trace mineral intake was higher for ITM $(\mathrm{Cu}, \mathrm{Mn}$, and Se) but tended $(P=0.07)$ to be higher for organic Zn. This was similar to other studies with TM where OTM intake was lower than ITM due to the content of minerals in the ITM mix (Kincaid et al., 2003; Kincaid and Socha, 2004; Kinal et al., 2005). This difference in the mineral content is due to the higher bioavailability of OTM; rations were formulated with a lower proportion of TM. Thus, feeding OTM may be a simple strategy to reduce TM excretion and contamination of the environment (Weiss and Spears, 2006; Spears, 2008). Evaluating TM intake, all TM presented a linear relationship with starch, decreasing when the level of starch increased. This is 
Table 2. Body weight, DMI, ADG, feed efficiency, and nutrient intake in precision-fed heifers with inorganic trace mineral (ITM) or organic trace mineral (OTM) treatments at 4 levels of starch intake ${ }^{1}$

\begin{tabular}{|c|c|c|c|c|c|c|c|c|c|}
\hline Item & $\mathrm{TM}$ & & & & & SEM & \multicolumn{3}{|c|}{ Contrast, $P$-value } \\
\hline \multirow[t]{2}{*}{$\overline{\mathrm{BW}},^{2} \mathrm{~kg}$} & OTM & 474.83 & 477.32 & 483.28 & 470.23 & 7.529 & 0.67 & 0.05 & 0.09 \\
\hline & ITM & 475.74 & 474.49 & 469.55 & 467.22 & & & & \\
\hline DMI, $\mathrm{kg} / \mathrm{kg}$ of $\mathrm{BW}^{0.75}$ & OTM & 8.574 & 8.681 & 8.302 & 7.832 & 0.070 & 0.68 & $<0.01$ & $<0.01$ \\
\hline DMI, $\%$ of BW & ITM & 1.793 & 1.822 & 1.750 & 1.671 & & & & \\
\hline \multirow[t]{2}{*}{$\mathrm{ADG}, \mathrm{kg} / \mathrm{d}$} & OTM & 0.722 & 0.995 & 0.986 & 0.642 & 0.140 & 0.81 & 0.87 & 0.02 \\
\hline & ITM & 0.806 & 0.867 & 0.839 & 0.688 & & & & \\
\hline \multirow[t]{2}{*}{ Feed efficiency $^{3}$} & OTM & 10.741 & 8.253 & 8.745 & 12.97 & 1.241 & 0.63 & 0.57 & 0.63 \\
\hline & ITM & 10.811 & 11.274 & 11.091 & 10.96 & & & & \\
\hline \multirow[t]{2}{*}{ Ash, $\mathrm{kg} / \mathrm{d}$} & OTM & 0.808 & 0.812 & 0.731 & 0.664 & 0.021 & 0.98 & 0.01 & 0.94 \\
\hline & ITM & 0.819 & 0.824 & 0.664 & 0.748 & & & & \\
\hline Hemicellulose ${ }^{4} \mathrm{~kg} / \mathrm{d}$ & ITM & 0.807 & 0.764 & 0.724 & 0.708 & & & & \\
\hline \multirow[t]{2}{*}{ Starch, $\mathrm{kg} / \mathrm{d}$} & OTM & 0.303 & 1.124 & 1.847 & 2.482 & 0.03 & 0.77 & $<0.01$ & $<0.01$ \\
\hline & ITM & 0.302 & 1.113 & 1.828 & 2.466 & & & & \\
\hline \multirow[t]{2}{*}{$\mathrm{CP}, \mathrm{kg} / \mathrm{d}$} & OTM & 1.271 & 1.316 & 1.250 & 1.234 & 0.029 & 0.45 & 0.04 & 0.64 \\
\hline & ITM & 1.281 & 1.277 & 1.212 & 1.229 & & & & \\
\hline \multirow[t]{2}{*}{$\mathrm{ME},{ }^{5} \mathrm{Mcal} / \mathrm{d}$} & OTM & 20.530 & 20.621 & 20.412 & 20.290 & 0.255 & 0.69 & 0.02 & 0.38 \\
\hline & ITM & 20.471 & 20.431 & 20.220 & 20.163 & & & & \\
\hline \multirow[t]{2}{*}{ Soluble sugar, $\mathrm{kg} / \mathrm{d}$} & OTM & 0.545 & 0.460 & 0.296 & 0.235 & 0.027 & 0.49 & $<0.01$ & 0.15 \\
\hline & ITM & 0.611 & 0.451 & 0.298 & 0.235 & & & & \\
\hline \multicolumn{10}{|l|}{ Trace mineral } \\
\hline \multirow[t]{2}{*}{$\mathrm{Cu}, \mathrm{mg} / \mathrm{d}$} & OTM & 145.16 & 142.82 & 134.35 & 130.31 & 3.887 & $<0.01$ & $<0.01$ & 0.15 \\
\hline & ITM & 183.79 & 181.79 & 170.62 & 156.17 & & & & \\
\hline $\mathrm{Mn}, \mathrm{mg} / \mathrm{d}$ & OTM & 754.81 & 729.28 & 620.50 & 493.61 & 20.228 & $<0.01$ & $<0.01$ & 0.02 \\
\hline
\end{tabular}

${ }^{1} \mathrm{TM}=$ trace mineral; $\mathrm{L}=$ linear; $\mathrm{Q}=$ quadratic.

${ }^{2}$ Average $\mathrm{BW}$ for the experiment.

${ }^{3} \mathrm{Kilograms}$ of DMI $/ \mathrm{kg}$ of ADG.

${ }^{4}$ Hemicellulose $=\mathrm{NDF}-\mathrm{ADF}$.

${ }^{5} \mathrm{ME}$ calculated as TDN $\times 0.04409 \times 0.82$.

because byproduct feeds used in the lower starch treatments naturally contained more TM than in the highstarch diets based on corn.

Apparent total-tract nutrient digestibilities are presented in Table 3. Type of TM did not affect DM, NDF, $\mathrm{ADF}$, hemicellulose, or starch digestibility. Overall, the different levels of starch only showed a tendency to affect DM digestibility, though DM digestibility increased linearly as starch increased in the $\operatorname{diet}(P=0.03)$. No interactions were detected between TM and fiber or starch. Digestibility of NDF and ADF was not affected by treatments. Hemicellulose digestibility was different by starch level $(P=0.03)$ and decreased linearly $(P=$ $0.02)$ as the starch proportion increased. The same was reported by Sarwar et al. (1991), where hemicellulose digestibility was higher in a diet that contained soybean hulls with low starch content. Even though starch digestibility did not change with the level of starch, the contrast analysis detected a linear effect with improved starch digestibility in the higher starch diets $(P$ $=0.05$ ). Specifically, the difference was more exaggerated for ITM. This suggests that amylolytic bacteria use OTM more efficiently (Little et al., 1958; Tiffany and Spears, 2005) and ferment OM more rapidly in the rumen, which also is supported by the observation of lower rumen $\mathrm{pH}$ (Figure 1). Overall, rate of passage increases as DMI increases (Robinson et al., 1987) and this has been shown to be true in precision-fed heif- 
Table 3. Nutrient apparent total-tract digestibility in precision-fed heifers with inorganic trace mineral (ITM) or organic trace mineral (OTM) treatments at 4 levels of starch intake ${ }^{1}$

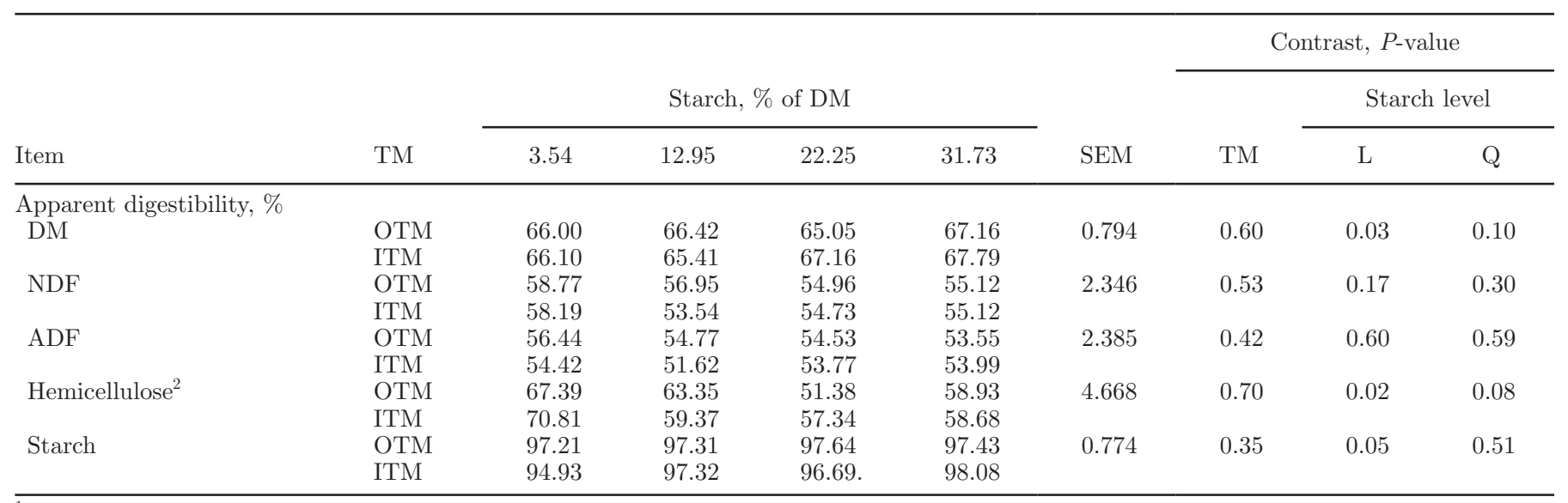

${ }^{1} \mathrm{TM}=$ trace mineral; $\mathrm{L}=$ linear; $\mathrm{Q}=$ quadratic.

${ }^{2}$ Hemicellulose $=$ NDF - ADF.

ers (Moody et al., 2007; Lascano and Heinrichs, 2011). In the present study, DMI was linearly reduced as the proportion of starch in the diet increased; then, rate of passage was higher at lower starch levels. This could suggest a higher ruminal digestibility with OTM and a lower starch digestibility of ITM diets with higher DMI.

\section{pH and Ruminal Fermentation}

Mean and minimum $\mathrm{pH}$ were lower for diets with OTM (Figure 1; Table 4), which is related to the higher total VFA production and butyrate proportion shown in Figure 2. Organic TM diets presented a higher total

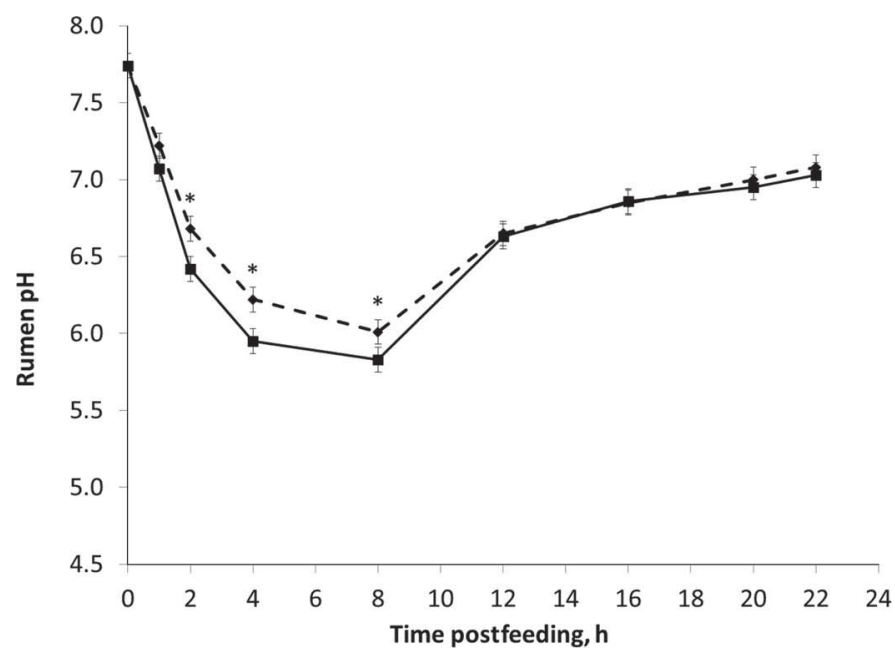

Figure 1. Rumen $\mathrm{pH}$ curve over $24 \mathrm{~h}$ in precision-fed heifers with inorganic trace mineral (dashed line) or organic trace mineral (solid line) treatments at 4 levels of starch intake. ${ }^{*} P$-value $<0.05$. Error bars represent SE.
VFA production $(P=0.08)$ at $4 \mathrm{~h}$ after feeding, and butyrate was higher $(P=0.01) 4$ to $8 \mathrm{~h}$ after feeding. Overall butyrate concentration was higher for OTM diets $(P=0.03)$. Butyrate concentration increased between 2 and $8 \mathrm{~h}$ after feeding, which corresponded with the low $\mathrm{pH}$ observed during 2 to $8 \mathrm{~h}$ after feeding. This can be explained by the shorter amount of time it took heifers to eat the meal, which was lower for OTM $(P=$ $0.05)$. As has been noted by other researchers (MalcolmCallis et al., 2000; Kincaid and Socha, 2004), inorganic forms of TM are less palatable because they are often offered as sulfates and oxalates. In this study, ITM were sulfate forms. Our results suggest that palatability of the OTM diet was better, which possibly explains why heifers ate faster, leading to a faster fermentation due to greater bioavailability of OTM. The catalytic effect on enzymatic processes, as well as structural and stabilizing functions of TM on microorganisms, can modify the metabolism of rumen bacteria and affect rumen fermentation (Durand and Kawashima, 1980). In this study, rumen $\mathrm{pH}$ was lower with OTM compared with ITM at 2, 4, and $8 \mathrm{~h}$ after feeding. This $\mathrm{pH}$ effect was probably due to higher bioavailability of OTM; faster replication of ruminal microorganisms would stimulate fermentation rate. This is concordant with Nikolic et al. (1976) who found that lower $\mathrm{pH}$ were associated with higher solubility of TM. Spears (1996) also commented that OTM presented higher ruminal soluble concentrations compared with ITM. In contrast, Oltjen et al. (1962) observed lower ruminal $\mathrm{pH}$ with diets containing high proportions of sulfates.

Volatile fatty acids are reported in Table 4, and variation of VFA concentrations throughout the day are presented in Figure 2. Total rumen VFA concentration was not different by treatment, but OTM resulted 
Table 4. Eating time, ruminal pH, and fermentation in precision-fed heifers with inorganic trace mineral (ITM) or organic trace mineral (OTM) treatments at 4 levels of starch intake ${ }^{1}$

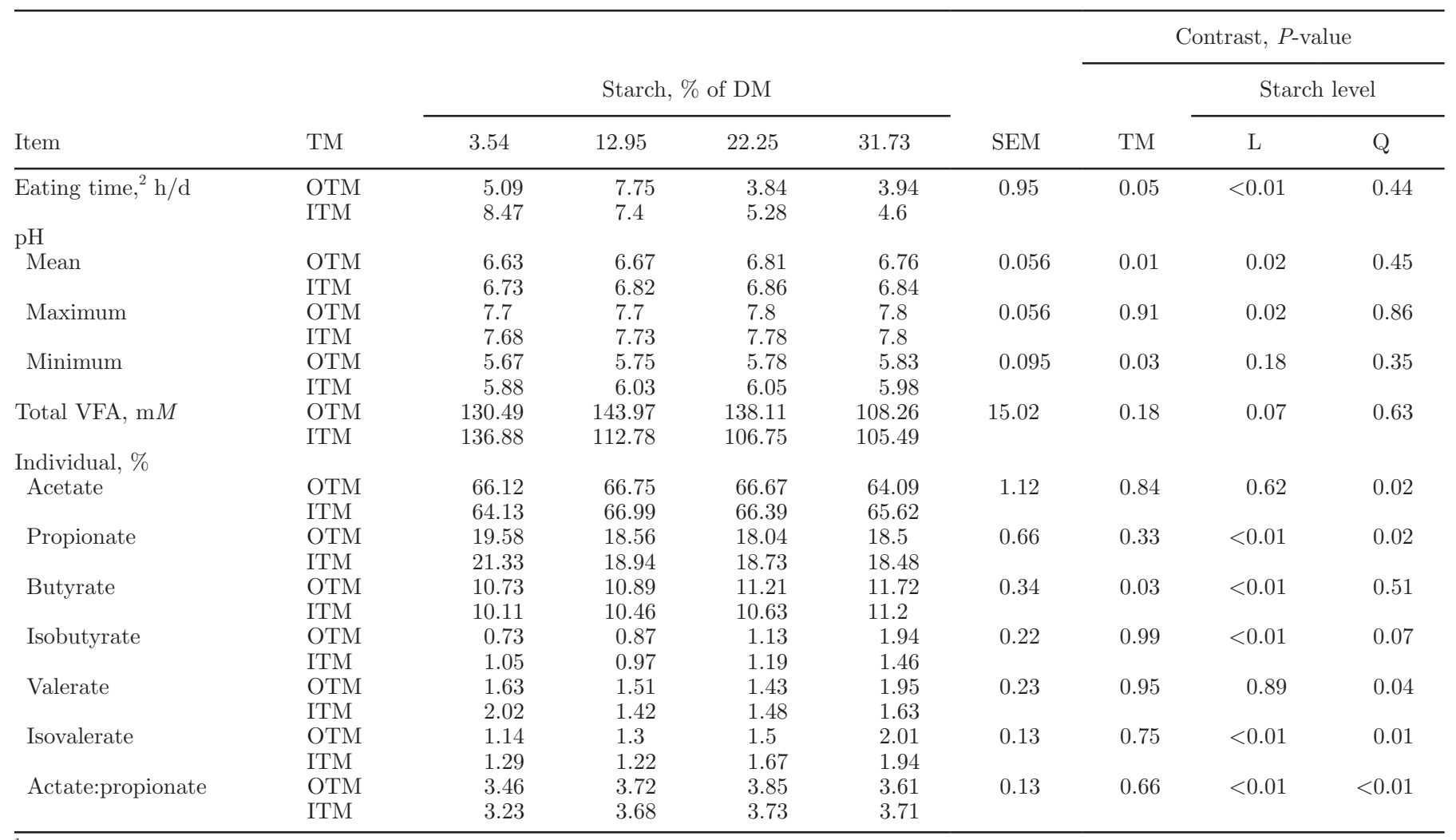

${ }^{1} \mathrm{TM}=$ trace mineral; $\mathrm{L}=$ linear; $\mathrm{Q}=$ quadratic.

${ }^{2}$ Eating time calculated from completion of the meal.

in an increased VFA concentration that was numerically higher between 1 and $20 \mathrm{~h}$ after feeding, showing a tendency $(P=0.08) 4 \mathrm{~h}$ after feeding (Figure $2 \mathrm{~A})$. Acetate molar proportion did not differ by treatment, but was higher for OTM $1 \mathrm{~h}$ after feeding (Figure 2B). Acetate showed a tendency to by influenced by a TM $\times$ starch interaction $(P=0.07)$. The opposite was observed for propionate, where the effect of ITM was higher propionate $1 \mathrm{~h}$ after feeding, but no difference was present between treatments overall (Figure 2C). Propionate concentrations showed a linear response to starch, decreasing as the proportion of starch increased in the diet. This can be justified due to the lower DMI of heifers when starch increased and also because of limit feeding heifers, thereby the total amount of feed available to be fermented is lower. On the other hand, butyrate concentration (Figure 2D) was higher in heifers fed OTM $(P=0.03)$ and linearly increased as the level of starch in the diet increased $(P=0.02)$. Acetate and acetate to propionate ratio showed a quadratic increase as diet starch concentration increased, with acetate peaking at $12.95 \%$ starch and the acetate to propionate ratio highest at $22.25 \%$ starch. Overall,
VFA values we observed were similar to the results of Lascano and Heinrichs (2009) with heifers on a 60:40 forage-to-concentrate ratio diet.

In general, higher total VFA production and butyrate concentration explain the low rumen $\mathrm{pH}$ observed in OTM diets. The rapid decline in $\mathrm{pH}$ might have affected cellulolytic bacteria, and therefore acetate production decreased the first $8 \mathrm{~h}$ after feeding. Similar data were reported by $\mathrm{Hu}$ et al. (2004), where fiber degradation decreased at $\mathrm{pH} 5.8$ and butyrate concentration increased at the same time point. In the present study, as the bioavailability of the OTM was higher (assumed based on previous studies with OTM; Spears, 1996, 2008), cellulolytic bacteria were able to use these TM immediately. As a result, fermentation of structural carbohydrates was faster, which is supported by the higher acetate proportion the first $4 \mathrm{~h}$ after feeding. As $\mathrm{pH}$ decreased under the optimal level for cellulolytic bacteria (Van Soest, 1994), it is possible that this group of bacteria took longer to recover the initial concentration. For that reason, after $4 \mathrm{~h}$ the acetate curve for OTM was under the curve of ITM. To our knowledge, no previous study has evaluated the effect 

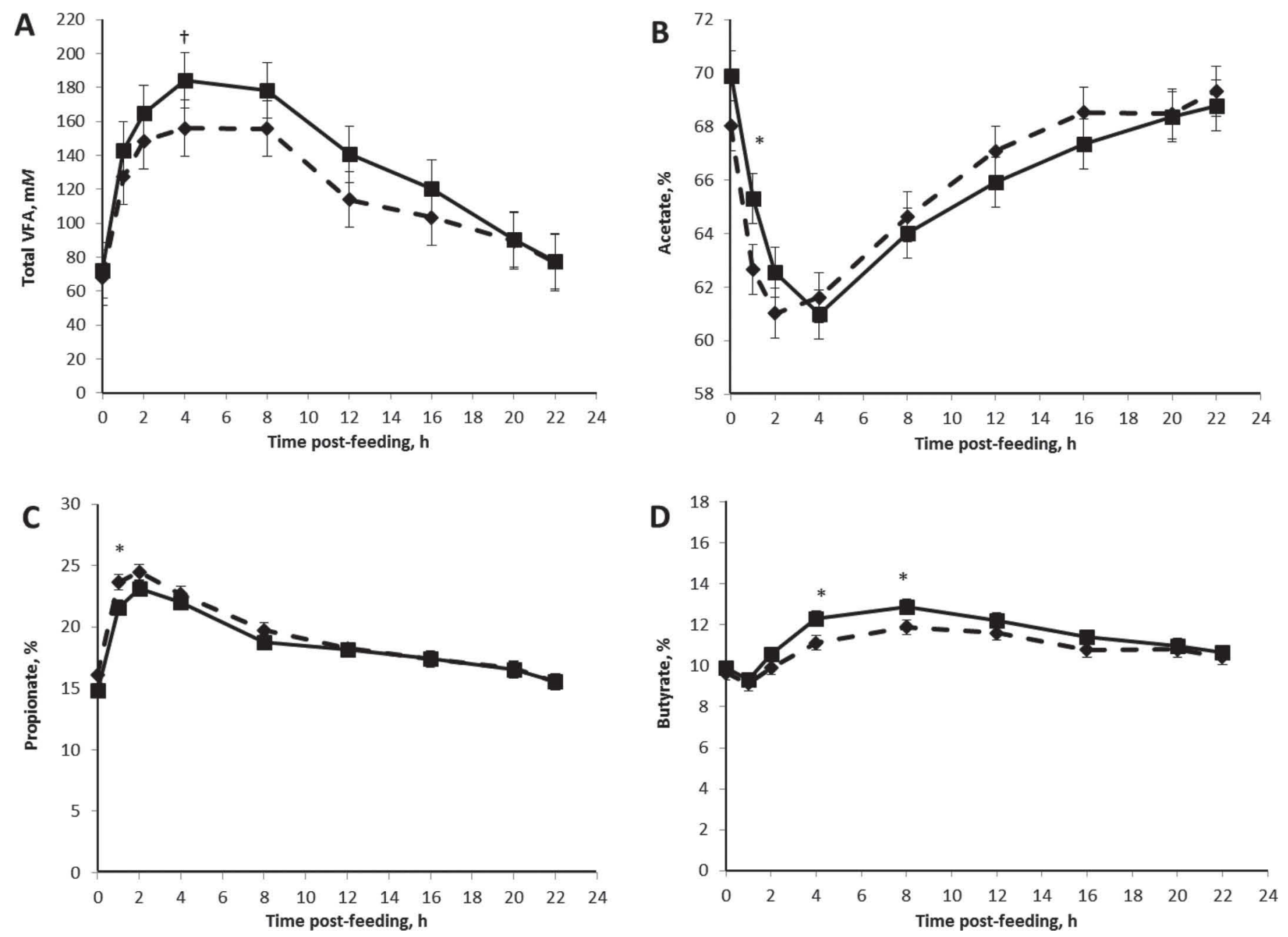

Figure 2. Fermentation end products over $24 \mathrm{~h}$ in precision-fed heifers with inorganic trace mineral (dashed lines) or organic trace mineral (solid lines) treatments at 4 levels of starch intake. (A) Total VFA, mM; (B) acetate, \%; (C) propionate, \%; (D) butyrate, \%. * $P$-value $<0.05$, $\dagger P$-value $<0.10$. Error bars represent SE.

of OTM on fermentation. Results of this study suggest that bacteria fermenting structural and nonstructural carbohydrates use more OTM and do so at a faster rate when compared with ITM, maximizing the fermentation process in the rumen with these diets.

\section{Excretion and Trace Minerals}

Manure production and TM excretion are presented in Table 5. Heifers were offered free choice water, and flow meters were used in an attempt to quantify water consumption. However, due to observations of heifers wasting water instead of drinking it, we were not able to accurately estimate consumption and those data are not reported. The percentage of dry feces as a percentage of wet feces is similar to that shown by Zanton and Heinrichs (2008) in heifers fed 1.5\% of BW as DM.
In this study, wet feces and total urine produced were higher for ITM (1.44 and $1.28 \mathrm{~kg}$ more respectively, $P$ $<0.01$ ), suggesting that water consumption was higher in heifers fed ITM. These changes led to an increase in total manure production $(P<0.01)$ that to our knowledge has not been described before in studies that compared total collection of feces in animals fed ITM or OTM. The difference in water consumption can be explained by the presence of sulfate salts that stimulate water intake in heifers fed the ITM supplement. On the contrary, OTM are formulated with proteins, AA, or yeasts that do not stimulate an increase in water intake, and OTM contain a lower concentration of TM as is shown in Table 2. Therefore, heifers fed ITM consumed more salts (sulfates) during the day and drank more water. This is supported by Marengo and Romani (2008) who found higher water intakes in diets with 
high contents of oxalates and by James and Butcher (1972) who found an increase in water consumption in sheep when oxalates increased in the diet. Similar results were found by Weeth and Hunter (1971), where water intake and diuresis increased in beef cattle that consumed more sulfates in water. Similarly, as described by Francesch and Brufau (2004) in broiler litter, fecal moisture increased when dietary electrolyte balance increased in the diet. Moreover, Patterson and Lorenz
(1996) stated that moisture in hen manure increased when hens were fed a diet with high content of minerals. In this study, the lower amount of manure produced in the OTM diet $(2.71 \pm 2.48 \mathrm{~kg} / \mathrm{d}$ per animal $)$ is an important finding, as it suggests OTM can be used as a strategy to decrease manure and its associated expenses for dairy farms. In addition, higher volumes of urine have a negative effect on the contamination of soils by increasing emission of nitrous oxide (Sherlock

Table 5. Excretion parameters in precision-fed heifers with inorganic trace mineral (ITM) or organic trace mineral (OTM) treatments at 4 levels of starch intake ${ }^{1}$

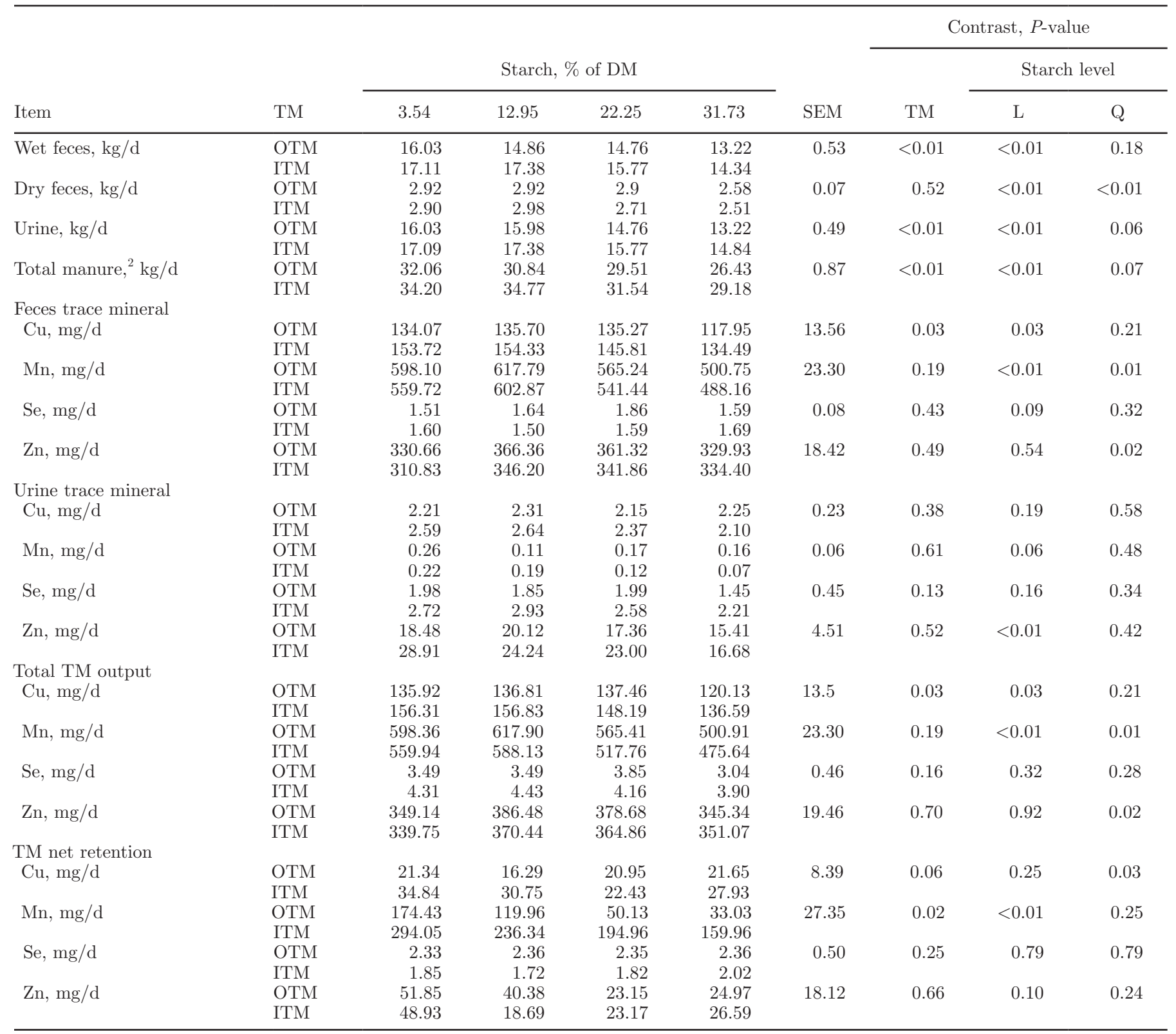

${ }^{1} \mathrm{TM}=$ trace mineral; $\mathrm{L}=$ linear; $\mathrm{Q}=$ quadratic.

${ }^{2}$ Feces included on as-is (wet) basis. 
and Goh, 1983). More studies are necessary to validate this observation in dairy cows, feedlots, and other species such as broilers to determine if OTM could have similar effects in these situations.

Wet feces, dry feces, urine, and total manure showed a linear relationship with the level of starch, decreasing as starch percentage of the diet increased. These changes were expected because increasing the starch content of the diets reduced DMI by design to maintain similar ME intakes. The same result was described by Zanton and Heinrichs (2008) in a study with limit-fed heifers offered different percentages of DMI. They described a linear effect on wet feces, urine, and total manure when DMI was increased as a percentage of BW. Similar results also were presented by Hoffman et al. (2007) where excretion was decreased linearly when DMI of heifers was reduced from ad libitum to $80 \%$ of ad libitum intake.

\section{Trace Mineral Analysis}

In Table 5, TM excretion is described. These results are similar to those presented by Gustafson (2000), who measured fecal and urine minerals in dairy cows fed with similar levels of TM. In our study, only fecal $\mathrm{Cu}$ was higher $(P<0.05)$ in the ITM treatment, whereas urinary $\mathrm{Cu}$ was numerically higher compared with the ITM diet. These results match the TM intake data, which were higher for ITM with the exception of Zn. The other mineral excretions were not different in feces or urine between TM forms. Level of starch did not affect overall TM excretion. Fecal selenium showed a tendency $(P=0.07)$ to be affected by a TM $\times$ starch interaction. A linear response was observed in fecal Mn, which decreased as starch level increased. This could be due to higher DMI in the lower starch diets and, hence, higher TM intake and excretion. In the same way, Zn excretion in urine was reduced linearly as starch level increased. The total output of individual TM was only different for $\mathrm{Cu}$, where the ITM excretion was higher than OTM $(P<0.05)$. This can also be explained by greater intake for ITM.

Apparent absorption is not shown in this study because for that is necessary to feed purified diets and it is used more for macro minerals (Ammerman et al., 1995). The net retention was higher for Mn $(P<0.05)$ in heifers fed with OTM. This agrees with results shown by (Beauchemin et al., 2006) in rats. Copper tended to be higher in heifers fed ITM $(P=0.06)$. Overall, these results indicate that even though intake of ITM was higher than OTM, retention was not different for Se and Zn for OTM. These results are similar to data shown by Nockels et al. (1993) and Spears (1996) where absorption increased and urinary excretion decreased with organic $\mathrm{Cu}$ and $\mathrm{Zn}$. Weiss (2008) showed a higher absorption of Mn when animals consumed OTM. Net retention is intake minus excretion, but excretion considers stored TM and TM in the mucosal layer of the gastointestinal tract. Thus, net retention as calculated here does not truly reflect storage or the amount of TM the animal used (Ammerman et al., 1995). In this way, net retention is a useful procedure to evaluate bioavailability of the TM in animals that show mineral deficiencies.

Plasma TM concentrations are reflected in Table 6. Starch did not affect plasma TM concentration. The type of TM in the diet did not affect $\mathrm{Cu}$ and $\mathrm{Se}$ concentration. However, plasma concentration for $\mathrm{Mn}$ was higher for heifers fed OTM and Zn was higher for heifers fed ITM. This is important because mineral intake was lower $(P<0.05$; Table 2$)$ in animals fed OTM. These data suggest that absorption of TM was higher in OTM, but plasma TM concentrations were not different between treatments. Previous studies that compared plasma concentration of ITM and OTM have resulted in variable responses. Kincaid and Socha (2004) and Kinal et al. (2005) observed the same results as the present study. They fed less OTM and did not observe differences in plasma concentration of TM. Others such as Harmon (2000) and Spears (1996) fed a similar amount of ITM or OTM and found higher plasma TM concentration for OTM.

It is important to state that plasma concentration of TM does not reflect the storage capacity or utilization of TM by animals that were not deficient before the experiment. Plasma levels only reflect the momentary concentration (Ammerman et al., 1995; Reynolds et al., 1998), and once absorbed, the TM are available to be stored or to be used by cells and physiological processes (Spears, 2003).

Enzymatic activity assays (ceruloplasmin, GPx, and SOD) were used to evaluate TM bioavailability. However, we did not observe any treatment effect in any of the assays used. Ceruloplasmin is a metalloenzyme that transports $\mathrm{Cu}$ in the blood. Ceruloplasmin activity decreased linearly as starch concentration increased. This can be explained because in the lower starch diets the proportion of byproducts was higher, and byproducts contain higher amounts of TM. Some studies explain that ceruloplasmin enzymatic activity changes only during deficiencies, and in these cases it is possible to observe differences between OTM and ITM (Underwood and Suttle, 1999). Blakley and Hamilton (1985) stated that plasma $\mathrm{Cu}$ concentration and ceruloplasmin activity were highly correlated. In this study, plasma TM concentration did not show differ- 
Table 6. Plasma trace mineral concentrations in precision-fed heifers with inorganic trace mineral (ITM) or organic trace mineral (OTM) treatments at 4 levels of starch intake ${ }^{1}$

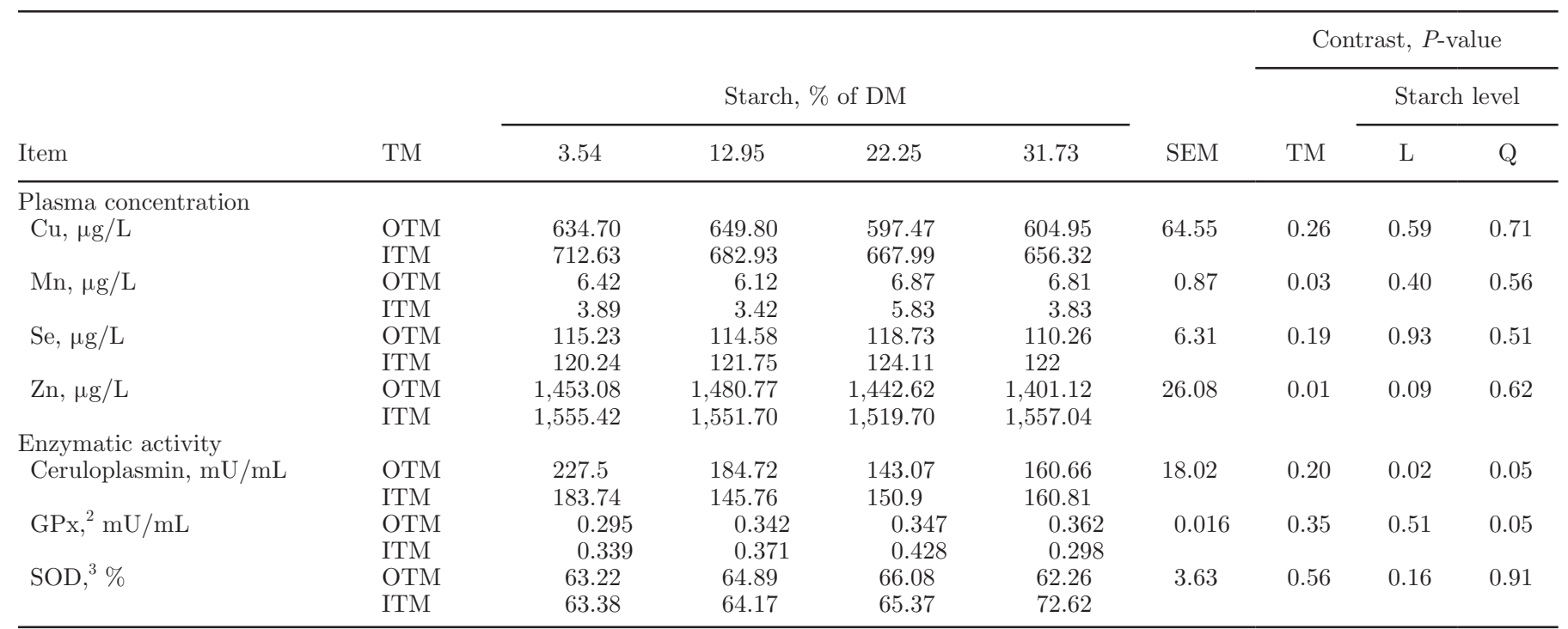

${ }^{1} \mathrm{TM}=$ trace mineral; $\mathrm{L}=$ linear; $\mathrm{Q}=$ quadratic.

${ }^{2} \mathrm{GPx}=$ glutathione peroxidase activity; $\mathrm{mU} / \mathrm{mL}=\mathrm{nmol} / \mathrm{min}$ per $\mathrm{mL}$.

${ }^{3} \mathrm{SOD}=$ superoxide dismutase activity; $\%$ of inhibition rate.

ences; thus, we cannot expect differences in activity. Ward et al. (1995) observed that ceruloplasmin activity can change depending on many factors, and one of them is breed. In lambs, Dezfoulian et al. (2012) found differences in ceruloplasmin activity between OTM and ITM, but Martin et al. (2011) did not find differences with the same treatments.

No differences were detected for activity of GPx. Selenium is an important component in the selenoproteins, among them GPx, participating directly in reduction reactions; GPx collaborates in detoxifying peroxide and prevents damage produced by free radicals in cells (they are toxic for all bacteria also). The mechanism is by catalyzing the reduction of peroxide and organic peroxides to stable alcohols and water. As with ceruloplasmin, the activity of GPx followed the same pattern of Se concentration in plasma. In this case, the GPx was numerically lower for OTM because plasma concentration of Se was also lower. The same was reported by Grace et al. (2001) who stated that feeds, plasma, and milk Se concentration are highly correlated with GPx. Also, the values reported in that study were very similar to the values reported here.

Ceruloplasmin, GPx, and Zn SOD activity were not different by treatment. Concentrations of $\mathrm{Zn}$ in plasma were higher for ITM, but SOD activity was not different, suggesting that the utilization of the OTM was higher. Dezfoulian et al. (2012) did not observe differences for SOD activity with ITM and OTM in lambs. The same was reported by Martin et al. (2011) in pigs.

\section{CONCLUSIONS}

Results of this experiment support the hypothesis that the type of TM affects rumen bacteria and produces responses in ruminal fermentation. The time that the heifers spent consuming the ration was lower for OTM suggesting better palatability. Digestibility of DM, NDF, ADF, hemicellulose, and starch was not affected by treatments. The OTM decreased rumen $\mathrm{pH}$ and increased total VFA production and butyrate concentration. This can be explained by the lower time consuming the ration with OTM, which led to a faster fermentation. Also the higher bioavailability of OTM suggests a faster utilization of the TM and accelerated replication of ruminal microorganisms, stimulating ruminal fermentation and VFA production. Butyrate was also affected by level of starch, showing a linear increment when starch level increased. In general, TM excretion was not affected by type of TM. Plasma TM concentration was not different by treatment except for $\mathrm{Mn}$ that was higher for OTM. However, mineral intake was reduced in OTM, but blood concentration was not different between TM type. These results suggest higher TM absorption of OTM compared with the ITM. Urine and total manure excretion were higher for ITM, suggesting that ITM stimulated water intake. Finally, type of TM affected rumen fermentation such that OTM was absorbed to a greater extent than ITM, suggesting higher bioavailability. Limited information is available about the effect of TM on rumen microor- 
ganisms; therefore, more research is necessary to evaluate and understand how microbes use TM and how important they are for rumen fermentation.

\section{ACKNOWLEDGMENTS}

Appreciation is extended to Natalie Urrutia of Penn State and Carla Castro of The University of Chile for laboratory assistance and data collection, to Coleen Jones of Penn State for her collaboration and editorial assistance, and to Alltech Inc. (Nicholasville, KY) for financial support.

\section{REFERENCES}

Ammerman, C. B., D. P. Baker, and A. J. Lewis. 1995. Bioavailability of Nutrients for Animals: Amino Acids, Minerals, Vitamins. Academic Press, San Diego, CA.

AOAC. 2000. Official Methods of Analysis. 17th ed. AOAC International, Gaithersburg, MD.

Beauchemin, K. A., C. R. Krehbiel, and C. J. Newbold. 2006. Enzymes, bacterial direct-fed microbials and yeast: principles for use in ruminant nutrition. Pages 251-284 in Biology of Growing Animals. Vol. 4. R. Mosenthin, J. Zentek and T. Żebrowska, ed. Elsevier, New York, NY.

Blakley, B. R., and D. L. Hamilton. 1985. Ceruloplasmin as an indicator of copper status in cattle and sheep. Can. J. Comp. Med. 49:405-408.

Cao, J., P. R. Henry, R. Guo, R. A. Holwerda, J. P. Toth, R. C. Littell, R. D. Miles, and C. B. Ammerman. 2000. Chemical characteristics and relative bioavailability of supplemental organic zinc sources for poultry and ruminants. J. Anim. Sci. 78:2039-2054.

Ciccioli, N. H., S. L. Charles-Edwards, C. Floyd, R. P. Wettemann, H. T. Purvis, K. S. Lusby, G. W. Horn, and D. L. Lalman. 2005. Incidence of puberty in beef heifers fed high- or low-starch diets for different periods before breeding. J. Anim. Sci. 83:2653-2662.

Cornelis, R., B. Heinzow, R. F. M. Herber, J. M. Christensen, O. M. Paulsen, E. Sabbioni, D. M. Templeton, Y. Thomassen, M. Vahter, and O. Vesterberg. 1995. Sample collection guidelines for trace elements in blood and urine. Pure Appl. Chem. 67:1575-1608.

Dezfoulian, A. H., H. Aliarabi, M. M. Tabatabaei, P. Zamani, D. Alipour, A. Bahari, and A. Fadayifar. 2012. Influence of different levels and sources of copper supplementation on performance, some blood parameters, nutrient digestibility and mineral balance in lambs. Livest. Sci. 147:9-19.

Durand, M., and R. Kawashima. 1980. Influence of minerals in rumen microbial digestion. Pages 375-408 in Digestive Physiology and Metabolism in Ruminants. Y. Ruckebusch and P. Thivend, ed. Springer, the Netherlands.

Francesch, M., and J. Brufau. 2004. Nutritional factors affecting excreta/litter moisture and quality. Worlds Poult. Sci. J. 60:64-75.

Grace, N. D., K. Ankenbauer-Perkins, A. M. Alexander, and R. M. Marchant. 2001. Relationship between blood selenium concentration or glutathione peroxidase activity, and milk selenium concentrations in New Zealand dairy cows. N. Z. Vet. J. 49:24-28.

Gustafson, G. M. 2000. Partitioning of nutrient and trace elements in feed among milk, faeces and urine by lactating dairy cows. Acta Agric. Scand. A 50:111-120.

Hall, M. B. 2009. Determination of starch, including maltooligosaccharides, in animal feeds: Comparison of methods and a method recommended for AOAC collaborative study. J. AOAC Int. 92:42-49.

Harmon, R. J. 2000. When are chelated minerals justified? Pages 4754 in Proc. Kentucky Ruminant Nutr. Workshop. University of Kentucky, Lexington.
Hoffman, P. C., C. R. Simson, and M. Wattiaux. 2007. Limit feeding of gravid Holstein heifers: Effect on growth, manure nutrient excretion, and subsequent early lactation performance. J. Dairy Sci. 90:946-954.

Hu, Z. H., G. Wang, and H. Q. Yu. 2004. Anaerobic degradation of cellulose by rumen microorganisms at various $\mathrm{pH}$ values. Biochem. Eng. J. 21:59-62.

Hubbert, F., E. Cheng, and W. Burroughs. 1958. Mineral requirement of rumen microorganisms for cellulose digestion in vitro. J. Anim. Sci. 17:559-568.

James, L. F., and J. E. Butcher. 1972. Halogeton poisoning of sheep: Effect of high level oxalate intake. J. Anim. Sci. 35:1233-1238.

Kenward, M. G., and J. H. Roger. 1997. Small sample inference for fixed effects from restricted maximum likelihood. Biometrics 53:983-997.

Kinal, S., A. Korniewicz, D. Jamroz, R. Zieminski, and M. Slupczynska. 2005. Dietary effects of zinc, copper and manganese chelates and sulphates on dairy cows. J. Food Agric. Environ. 3:168-172.

Kincaid, R. L., L. E. Lefebvre, J. D. Cronrath, M. T. Socha, and A. B. Johnson. 2003. Effect of dietary cobalt supplementation on cobalt metabolism and performance of dairy cattle. J. Dairy Sci. $86: 1405-1414$.

Kincaid, R. L., and M. T. Socha. 2004. Inorganic versus complexed trace mineral supplements on performance of dairy cows. Prof. Anim. Sci. 20:66-73.

Lascano, G. J., and A. J. Heinrichs. 2009. Rumen fermentation pattern of dairy heifers fed restricted amounts of low, medium, and high concentrate diets without and with yeast culture. Livest. Sci. 124:48-57.

Lascano, G. J., and A. J. Heinrichs. 2011. Effects of feeding different levels of dietary fiber through the addition of corn stover on nutrient utilization of dairy heifers precision-fed high and low concentrate diets. J. Dairy Sci. 94:3025-3036.

Lascano, G. J., G. I. Zanton, A. J. Heinrichs, and W. P. Weiss. 2010. Technical note: A noninvasive urine collection device for female cattle: Modification of the urine cup collection method. J. Dairy Sci. 93:2691-2694.

Lascano, G. J., G. I. Zanton, F. X. Suarez-Mena, and A. J. Heinrichs. 2009. Effect of limit feeding high- and low-concentrate diets with Saccharomyces cerevisiae on digestibility and on dairy heifer growth and first-lactation performance. J. Dairy Sci. 92:5100-5110.

Little, O., E. Cheng, and W. Burroughs. 1958. Effects of chelating agents on cellulose digestion in vitro by rumen. J. Anim. Sci. 17:1190. (Abstr.)

Malcolm-Callis, K. J., G. C. Duff, S. A. Gunter, E. B. Kegley, and D. A. Vermeire. 2000. Effects of supplemental zinc concentration and source on performance, carcass characteristics, and serum values in finishing beef steers. J. Anim. Sci. 78:2801-2808.

Marengo, S. R., and A. M. Romani. 2008. Oxalate in renal stone disease: The terminal metabolite that just won't go away. Nat. Clin. Pract. Nephrol. 4:368-377.

Martin, R. E., D. C. Mahan, G. M. Hill, J. E. Link, and J. S. Jolliff. 2011. Effect of dietary organic microminerals on starter pig performance, tissue mineral concentrations, and liver and plasma enzyme activities. J. Anim. Sci. 89:1042-1055.

Moody, M. L., G. I. Zanton, J. M. Daubert, and A. J. Heinrichs. 2007. Nutrient utilization of differing forage-to-concentrate ratios by growing Holstein heifers. J. Dairy Sci. 90:5580-5586.

Nikolic, J. A., M. Jovanovic, and R. Andric. 1976. Determination of possible effects of mineral concentration on protein synthesis by rumen microbes in vitro. Pages 89-96 in Tracer Studies on NonProtein Nitrogen for Ruminants II. Int. Atomic Energy Agency, Vienna, Austria.

Nockels, C. F., J. DeBonis, and J. Torrent. 1993. Stress induction affects copper and zinc balance in calves fed organic and inorganic copper and zinc sources. J. Anim. Sci. 71:2539-2545.

NRC. 2001. Nutrient Requirements of Dairy Cattle. 7 th rev. ed. Natl. Acad. Press, Washington, DC. 
Oltjen, R. R., R. J. Sirny, and A. D. Tillman. 1962. Effects of B vitamins and mineral mixtures upon growth and rumen function of ruminants fed purified diet. J. Nutr. 77:269-277.

Patterson, P. H., and E. S. Lorenz. 1996. Manure nutrient production from commercial white leghorn hens. J. Appl. Poult. Res. $5: 260-268$.

Pino, F. H., and A. J. Heinrichs. 2014. Comparison of on-farm foragedry-matter methods to forced-air oven for determining forage dry matter. Prof. Anim. Sci. 30:33-36.

Piwonka, E. J., J. L. Firkins, and B. L. Hull. 1994. Digestion in the rumen and total tract of forage-based diets with starch or dextrose supplements fed to Holstein heifers. J. Dairy Sci. 77:1570-1579.

Reynolds, N., A. Blumsohn, J. P. Baxter, G. Houston, and C. R. Pennington. 1998. Manganese requirement and toxicity in patients on home parenteral nutrition. Clin. Nutr. 17:227-230.

Robinson, P. H., S. Tamminga, and A. M. Van Vuuren. 1987. Influence of declining level of feed intake and varying the proportion of starch in the concentrate on rumen ingesta quantity, composition and kinetics of ingesta turnover in dairy cows. Livest. Prod. Sci. $17: 37-62$.

Rodushkin, I., T. Ruth, and A. Huhtasaari. 1999. Comparison of two digestion methods for elemental determinations in plant material by ICP techniques. Anal. Chim. Acta 378:191-200.

Sarwar, M., J. L. Firkins, and M. L. Eastridge. 1991. Effect of replacing neutral detergent fiber of forage with soyhulls and corn gluten feed for dairy heifers. J. Dairy Sci. 74:1006-1017.

Sherlock, R. R., and K. M. Goh. 1983. Initial emission of nitrous oxide from sheep urine applied to pasture soil. Soil Biol. Biochem. 15:615-617.

Spears, J. W. 1996. Organic trace minerals in ruminant nutrition. Anim. Feed Sci. Technol. 58:151-163.

Spears, J. W. 2003. Trace mineral bioavailability in ruminants. J. Nutr. 133:1506S-1509S.

Spears, J. W. 2008. Trace mineral nutrition-What is important and where do organic trace minerals fit? Proc. Southwest Nutr. Management Conf., University of Arizona, Tucson. Accessed Jan. 20, 2016. www.researchgate.net/publication/228586907_ Trace_Mineral_Nutrition-What_is_Important_and_Where_do_ Organic_Trace_Minerals_Fit_in.

Storm, A. C., N. B. Kristensen, and M. D. Hanigan. 2012. A model of ruminal volatile fatty acid absorption kinetics and rumen epithelial blood flow in lactating Holstein cows. J. Dairy Sci. 95:2919-2934.
Summers, C. E., F. H. Baker, and R. B. Grainger. 1957. Cellulolytic interrelationships of carbohydrates, fat and trace minerals in sheep rations. J. Anim. Sci. 16:781-786.

Tiffany, M. E., and J. W. Spears. 2005. Differential responses to dietary cobalt in finishing steers fed corn- versus barley-based diets. J. Anim. Sci. 83:2580-2589.

Underwood, E. J., and N. F. Suttle. 1999. The Mineral Nutrition of Livestock. 3rd ed. CAB International, Boston, MA.

Van Soest, P. J. 1994. Nutritional Ecology of the Ruminant. 2nd ed Cornell Univ. Press, Ithaca, NY.

Van Soest, P. J., J. B. Robertson, and B. A. Lewis. 1991. Methods for dietary fiber, neutral detergent fiber, and nonstarch polysaccharides in relation to animal nutrition. J. Dairy Sci. 74:3583-3597.

Vaughan, M. A., A. D. Baines, and D. M. Templeton. 1991. Multielement analysis of biological samples by inductively coupled plasmamass spectrometry. II. Rapid survey method for profiling trace elements in body fluids. Clin. Chem. 37:210-215.

Ward, J. D., J. W. Spears, and G. P. Gengelbach. 1995. Differences in copper status and copper metabolism among Angus, Simmental, and Charolais cattle. J. Anim. Sci. 73:571-577.

Weeth, H. J., and J. E. Hunter. 1971. Drinking of sulfate-water by cattle. J. Anim. Sci. 32:277-281.

Weiss, W. P. 2008. Update on trace mineral requirements for dairy cattle. Pages 13-21 in Proc. 2008 Four-State Dairy Nutr. Mgmt Conf., Univ. of Wisconsin, Madison, WI.

Weiss, W. P., and J. W. Spears. 2006. Vitamin and trace mineral effects on immune function of ruminants. Pages 473-496 in Ruminant Physiology: Digestion, Metabolism and Impact of Nutrition on Gene Expression, Immunology and Stress. Wageningen Academic Publishers, Utrecht, the Netherlands.

Yang, C. M. J., and G. A. Varga. 1989. Effect of three concentrate feeding frequencies on rumen protozoa, rumen digesta kinetics, and milk yield in dairy cows. J. Dairy Sci. 72:950-957.

Zanton, G. I., and A. J. Heinrichs. 2007. The effects of controlled feeding of a high-forage or high-concentrate ration on heifer growth and first-lactation milk production. J. Dairy Sci. 90:3388-3396.

Zanton, G. I., and A. J. Heinrichs. 2008. Rumen digestion and nutritional efficiency of dairy heifers limit-fed a high forage ration to four levels of dry matter intake. J. Dairy Sci. 91:3579-3588. 